\title{
The Reproduction of Cultural Aspects in Dictionaries in French and the Gabonese Languages*
}

\author{
P.A. Mavoungou (moudika2@yahoo.fr), Thierry Afane Otsaga \\ (thiafane@yahoo.fr) and Guy-Roger Mihindou \\ (guyr_mihindou@hotmail.com), Department of Afrikaans and Dutch, \\ University of Stellenbosch, Stellenbosch, Republic of South Africa
}

\begin{abstract}
The reproduction of culture in dictionaries constitutes one of the fundamental problems of lexicographers today. What is the nature of cultural data in dictionaries? To what extent should cultural aspects be transferred from one language to another? How should this transfer take place? This article attempts to discuss the relevance of the reproduction of Gabonese cultural aspects in dictionaries in French and the Gabonese languages. One of the main problems the compilers of these dictionaries encountered was the transfer and the translation of some cultural aspects.

In order to discuss the nature and extent of cultural information in Gabonese dictionaries, this article will restrict itself to the following points:

$\begin{array}{ll}\text { - } & \text { The translation of different realities } \\ \text { - } & \text { The role of culture in the change of meaning } \\ \text { - } & \text { Dictionaries and cultural activities } \\ \text { - } & \text { Dictionaries and cultural ethics } \\ \text { - } & \text { Dictionaries and language registers } \\ \text { - } & \text { Dictionaries and culture maintenance } \\ \text { - } & \text { Dictionaries and the standardization of culture }\end{array}$

Prior to a discussion of the above-mentioned points, a brief description of the dictionaries investigated will be given. After a description of the influence of cultural contexts on lexicographers in the choice of macrostructural elements and their treatment, cultural differences between source and target languages in the dictionaries of Gabonese languages are discussed. The article concludes with the observation that the majority of existing lexicographic works tend to survey the full vocabulary of the language. The lexicographic treatment of some words is satisfactory because an account of the underlying worldview of the people is given. For example, in this article, the following themes are considered: dietary practices, sexuality, mythology, traditional pharmacopoeia, the kinship system, hospitality, and respect for traditional authority and elders. However, to be used in the most efficient way, these lexicographic publications need to be revised.
\end{abstract}

Keywords: CULTURE, DICTIONARIES, TARGET USER, TRANSLATION, CULTURAL

This article was presented as a paper at the Seventh International Conference of the African Association for Lexicography, organised by the Dictionary Unit of South African English, Rhodes University, Grahamstown, 8-10 July 2002. 
ACTIVITIES, CULTURAL ETHICS, LANGUAGE LEVELS, CULTURE MAINTENANCE, STANDARDIZATION OF CULTURE, GABONESE LANGUAGES

Résumé: La reproduction des aspects culturels dans les dictionnaires en français et en langues gabonaises. La reproduction de la culture dans les dictionnaires constitue l'un des problèmes fondamentaux des lexicographes aujourd'hui. Quelle est la nature des données culturelles dans les dictionnaires? Jusqu'à quel point les données culturelles doivent-elles être transférées d'une langue à une autre? Comment ce transfert doit-il se faire? Cet article tente d'examiner la pertinence de la reproduction des aspects des cultures gabonaises dans les dictionnaires en français et en langues gabonaises. L'un des principaux problèmes rencontrés par les rédacteurs de ses dictionnaires était le transfert et la traduction de certains aspects culturels.

Pour discuter de la nature et du degré des informations culturelles dans les dictionnaires en langues gabonaises, cet article va se limiter aux points suivants:

$$
\begin{array}{ll}
\text { - } & \text { La traduction de différentes réalités } \\
\text { - } & \text { Le rôle de la culture dans le changement du sens } \\
\text { - } & \text { Les dictionnaires et les activités culturelles } \\
\text { - } & \text { Les dictionnaires et la morale culturelle } \\
\text { - } & \text { Les dictionnaires et les registres de langue } \\
\text { - } & \text { Les dictionnaires et la maintenance de la culture } \\
\text { - } & \text { Les dictionnaires et la standardisation de la culture }
\end{array}
$$

Avant une discussion des points sus-mentionnés, une brève description des dictionnaires examinés sera donnée. Après une description de l'influence des contextes culturels dans le choix des éléments macrostructuraux ainsi que de leur traitement, les divergences culturelles entre languessources et langues-cibles dans les dictionnaires en langues gabonaises seront examinés. L'article conclut par l'observation que la majorité des travaux lexicographiques existants tente de donner un aperçu du lexique total de la langue. Le traitement lexicographique de certains mots est satisfaisant parce qu'il prend en compte la vision du monde sous-jacente des populations. Par exemple, dans cet article, les thèmes suivants sont pris en compte: habitudes alimentaires, sexualité, mythologie, pharmacopée traditionnelle, système de parenté, hospitalité, et le respect de l'autorité traditionnelle et des aînés. Cependant, pour être utilisées de la manière la plus efficace, ses publications lexicographiques méritent d'être révisées.

Mots-clés: CULTURE, DICTIONNAIRES, PUBLIC CIBLE, TRADUCTION, ACTIVITÉS CULTURELLES, CULTURE MORALE, NIVEAUX DE LANGUE, MAINTENANCE CULTURELLE, STANDARDISATION DE LA CULTURE, LANGUES GABONAISES

\section{Introduction}

In present-day lexicography, there is a tendency to give an account of the underlying culture and civilization of the languages being described. However, reservations can be made with regard to an encyclopaedic bias. Too often lexicographers compiling dictionaries in the languages in question have been focusing on encyclopaedic or extra-linguistic aspects of the lemma instead of on linguistic data. 
The majority of dictionaries available in Gabonese languages have a common denominator: they are translation dictionaries and were compiled by Catholic and Protestant missionaries or colonial administrators (cf. Mavoungou 2001a: 160). One of the main problems the compilers of these dictionaries encountered, was the transfer and the translation of certain cultural aspects from one language to another. In fact, the lexicographer does not only propose the description of the lexicon, but should also take the context of use into account. The dictionary is a mirror in which the user must recognize himself not only as speaker but also as a member of a cultural community (Dubois and Dubois 1971).

Gabonese dictionaries are investigated here with a view to comparing how the cultural transfer is taking place as well as its limitations. An attempt will be made to answer the following questions: What is the nature and extent of cultural information in existing Gabonese dictionaries? How can the cultural transfer of information in these dictionaries be improved? Moreover, various cultural gaps between source and target languages in the existing dictionaries will be shown as well as the ways cultural and environmental contexts have influenced lexicographers in the choice of macrostructural elements and their treatment.

Before discussing these, a brief description of the dictionaries investigated will be given. The dictionaries will be restricted to the following:

- Encyclopédie pahouine, Largeau (1901),

- Lexique fãn-français, Martrou (1924),

- Les plantes utiles du Gabon, Raponda-Walker and Sillans (1961),

- Dictionnaire fang-français et français-fang, suivi d'une grammaire fang, Galley (1964),

- Dictionnaire français-yipounou, yipounou-français, Église Évangélique du Sud-Gabon (1966),

- Dictionnaire Français-Mpongwé, Raponda-Walker (19952), and

_ _ "Lexique" in Nsuka-Nkutsi (Ed.), Rittaud-Hutinet (1980).

\section{A brief description of the investigated dictionaries}

\subsection{The Encyclopédie pahouine of Largeau (1901)}

The colonial administrator Largeau published the Encyclopédie pahouine in 1901. It is an alphabetically arranged dictionary of considerable size, consisting of \pm 4996 articles and covering 699 pages. The value of the work lies in the useful information regarding the history of the Fang people, their value system as well as other anthropological issues such as rituals and mythology which the 
user can find in its introductory section. It also contains special articles focusing on cultural data introduced by the structural marker Encyclopédie, as well as the systematic use of literal translations aimed at the translation equivalents and competence examples (cf. Nyangone Assam and Mavoungou 2000: 257 and Mavoungou 2001: 127 respectively).

\subsection{The Lexique fãn-français of Martrou (1924)}

The Lexique fãn-français published in 1924 by Archbishop Martrou, is an alphabetically arranged lexicon consisting of 3431 articles covering 137 pages. Although the title of this publication modestly describes it as a "lexicon", it is in fact a comprehensive and thorough dictionary.

The user is provided with various data categories: paraphrases of meaning, translation equivalents, competence examples, etc. Many typographical structural markers such as roman, italic, bold and small characters are used in the work to fulfil a metacommunicative function. However, the lexicon does not clearly identify its target users or their reference skills. Martrou's lexicon also fails to give an account of its primary and secondary sources (Mavoungou 2001: 127-130).

\subsection{Les plantes utiles du Gabon of Raponda-Walker and Sillans (1961)}

Although entitled Les plantes utiles $d u$ Gabon, this publication is in fact an encyclopedic dictionary of the names and uses of Gabonese plants, published in 1961 by Raponda-Walker in collaboration with Sillans. It is arranged alphabetically, and consists of 1497 articles covering 582 pages. It contains some 8000 indigenous plant names (as well as their scientific names and usages), collected over a period of thirty years by Raponda-Walker. The work gives an account of its primary, secondary and tertiary sources and the front and back matter texts are also sources of valuable information for the users concerning the scientific description (height and diameter, arrangement and texture of the foliage and leaves, etc.), and the distribution and the cultivation requirements of the tree dealt with. As visual aids for users, the book is illustrated with 53 pictures by Sillans (cf. Nyangone Assam and Mavoungou 2000: 271 and Mavoungou 2001a: 169-174).

\subsection{The Dictionnaire fang-français et français-fang, suivi d'une grammaire fang of Galley (1964)}

The Dictionnaire fang-français et français-fang by the Genevan pastor Samuel Galley was published in 1964. It is an alphabetically arranged bilingual dictionary consisting of \pm 13925 articles and covering 588 pages. It is based on the translation of the Bible in Fang, another gigantic task Galley undertook for the Fang community of Talagouga. 
The value of the work lies in its biscopal character. The microstructure includes a considerable amount of data, e.g. parts of speech, class numbers, translation equivalents, meaning explanations as well as cross-references (cf. Nyangone Assam and Mavoungou 2000: 258).

\subsection{The Dictionnaire français-yipounou, yipounou-français of the Église Evangélique du Sud-Gabon (1966)}

The Dictionnaire français-yipounou, yipounou-français of the Christian and Missionary Alliance (CMA) was published in 1966. It is an alphabetically arranged bilingual publication consisting of 8934 articles and covering 145 pages. In the front matter, the compilers, American missionaries, make it clear that the work, published for a target group of Yipunu mother-tongue speakers, is meant to help them in studying the Bible (cf. Mihindou 2001: 26). Although this publication is described as a "dictionary", it is in fact only a glossary. In the first section, macro- and microstructural data include lemmata in French followed by their Yipunu translation equivalents presented in two columns, whereas in the second section this information appears in the reversed direction, Yipunu followed by French.

\subsection{The Dictionnaire Français-Mpongwé of Raponda-Walker (1995²)}

The Dictionnaire Français-Mpongwé of Raponda-Walker was published for the first time by the Imprimerie de la Libre Lorraine in Metz (1930-1934). It is monoscopal, with Mpongwé as source and French as target language. In 1961, 27 years later, the dictionary was published in the reverse direction, FrenchMpongwé, by the Imprimerie Saint Paul in Brazzaville. This version of the dictionary was reprinted in 1995 under the auspices of the Raponda-Walker Foundation (cf. Nyangone Assam and Mavoungou 2000: 260).

This last version of the dictionary (that will be investigated in this study) is an alphabetically arranged bilingual publication consisting of some 8000 articles and covering 723 pages. The dictionary articles include much data, such as lemmata in French, translation equivalents in Mpongwé, part of speech indicators, labels, illustrative examples, etc.

\section{7 "Lexique" in Nsuka-Nkutsi (Ed.) of Rittaud-Hutinet (1980)}

The work of Rittaud-Hutinet entitled "Lexique" was published in 1980. It is an alphabetically arranged bilingual Yipunu-French lexicon consisting of 945 articles and covering 52 pages. The publication is based on several sources, its primary source being a questionnaire from Joseph H. Greenberg. Moreover, the lexicographer gives an account of the criteria for the incorporation of all the lexical items (nouns, verbs, adjectives, pronouns, etc.) entered in the lexicon according to the stem tradition. 
3. The nature and extent of cultural information in the existing Gabonese dictionaries

The discussion of the nature and extent of cultural information in existing Gabonese dictionaries will be restricted to the following focus areas:

- The translation of different realities

- The role of culture in the change of meaning

- Dictionaries and cultural activities

- Dictionaries and cultural ethics

- Dictionaries and language registers

- Dictionaries and culture maintenance

- Dictionaries and the standardization of culture

\subsection{The translation of different realities}

No matter what its typology is, a dictionary is a description of culture (Dubois and Dubois 1971). The translation of a culture in a language to which it is uncommon or unknown, is never easy. In such cases, the lexicographer has to be careful regarding the context and the environment of the dictionary users.

In some dictionaries of Gabonese languages, the French National Day 14 juillet, for instance, has been translated as 'emu awom benin' (14th July) in Fang. This translation is meaningless to a Fang speaker, who will not recognise the relation between July 14 and the French National Day. The best way to translate this concept is to use the meaning paraphrase 'emu France anga nyong fili' ("the day France got freedom"). In the same way, August 17 is defined by the meaning paraphrase 'emu Gabon anga nyong fili' ("the day Gabon got freedom"), used by Fang speakers to designate the Gabonese Independence Day.

Numerous examples of the same kind can be found in existing dictionaries of Gabonese languages. The Gabonese, for instance, will not understand the term "crucify", because this practice (the crucifixion) does not exist in Gabonese cultures. In Western cultures, this term primarily designates the death of Jesus Christ. This point is illustrated by the treatment of the article of the lemma crucifier.

(1) Dictionary excerpt from Galley 1964: 447.

CRUCIFIER quelqu'un, domele môr éli (hbh). Crucifié, ñkelba éli (bh)

In this case, the concept crucifixion should be substituted by a term designating the same reality in Gabonese languages (e.g. hanging). 


\subsection{The role of culture in the change of meaning}

Cultural gaps between Gabonese and European languages (French in particular) play an important role in the change of meaning of numerous current words. As far as French is concerned, many words do have another meaning in the Gabonese environment as compared to the meaning they have in French society. The term cadeau for example, firstly means "present" or "gift" in French. In the context of Gabonese languages, this term also means "free" or "gratis". In existing Gabonese dictionaries, these cultural specificities have not been taken into account as is clearly shown in (2) and (3).

(2) Dictionary excerpt from Galley 1964: 431.

CADEAu don, évévé (h) (exactement éveévé). Cadeau empaqueté et envoyé à un ami pour une occasion, atôm (h). Cadeau quelconque, n'importe quoi, ékeélé (bm). Cadeau à celui qui part, promesse, meyagha (h), magha (h). Cadeau qu'on apporte à un ami quand on va en visite chez lui, meyeñ (h). Cadeau, souvenir d'un ami à son ami, objet qui lui a appartenu, mvôm (bb). Cadeau offert par crainte et pour calmer quelqu'un, ndun (h), ntun (h), ntãn abi (hh). Cadeaux de la belle-famille (abè) au gendre, ñgañ (m), mevale $(\mathrm{h})$.

(3) Dictionary excerpt from Raponda-Walker 1995: 69.

cadeau N. kado, dasi (néol.). Cadeau donné, eza zi mpagaga; cadeau reçu, eza zi mpagago.

Petit cadeau, izege. Cadeau de bienvenue, asango.

In Gabonese French, as mentioned above, the word "cadeau" is not only used in the sense of "present" or "gift" but also in the sense of "free" or "gratis". Articles (2) and (3) do not account for the sense "free" or "gratis". This is detrimental to users because it is well attested that in any translation dictionary with English as a treated language, the focus should be on one variety of English, e.g. British or American English. However, when including lexical items restricted to a variety exclusively used by the target users of the dictionary, the lexicographer should indicate this restricted usage by employing a system of geographical labels. The same line of argumentation holds true for French. French is nowadays geographically dispersed across a significant number of continents and countries. The geographical dispersal of French has brought the language into daily contact with new usages in French-speaking countries and territories in Europe, North America, Africa and Asia. This has strengthened and enriched French as it is spoken in France. Thus it is important that dictionaries should take account of the usage of French spoken outside France, especially as it influences the form used in France (cf. Mavoungou 2002). As far as the treatment of the article of the lemma cadeau is concerned, e.g. in Galley (1964) and Raponda-Walker (1995), both compilers have failed to take cognisance of the differences between Gabonese French and French as it is spoken in France, and 
to supply the target users with the necessary data.

Despite the shortcoming of the article on cadeau in the Dictionnaire Français-Mpongwé, this dictionary with its 8000 articles contains quite a representative lexis of national and local forms of French. Since these items relate to Gabonese cultures, they deserve special mention. The first illustration in this regard comes from the article of the lemma levée:

(4) Dictionary excerpt from Raponda-Walker 1995: 382.

levée N. (de terre) oralyo; (de deuil) intsugu. Danser à cette occasion, boliz'intsugu.

Moreover, there are, among others, seventeen articles that can be labelled as Gabonese French, viz. caïman, concombre, fromager, hangar, homonyme, kapok, kapokier, kinkéliba, levée de terre, règle, taloche, sanglier, talocher, cassada, blinder, chat huant, and gris-gris. Of these seventeen, four lexical items, namely kapok, kapokier, kinkéliba (or quinquéliba) and gris-gris, are widely used in the French-speaking world.

A further six, viz. caïman, levée de terre, concombre, hangar, homonyme, and sanglier contain a great deal of information about fauna and flora and have a special relevance for Gabonese cultures. A brief examination of these reveals that caïman "a crocodile found in America" and sanglier "a bush-pig mainly found in Europe" are the local forms of French used to refer to Osteolaemus tetrapis (or Crocodylus niloticus) and Potamochoerus porcus respectively. Similarly, the lexical item concombre "cucumber" does not refer to the same extra-linguistic reality in France and in Gabon. In the former, people easily assimilate concombre to the French courge because the two belong to the same family Cucurbitaceae. In the Gabonese context, the lexical item hangar encompasses a slightly different meaning compared to that in France. In Gabon, it does not only refer to a warehouse but it is primarily a building where the local population goes to worship ancestral spirits or tutelary spirits (cf. Mavoungou 2002). In Africa like elsewhere in the world, the naming of a child is a matter of great importance. In the Gabonese context, homonyme "homonym" is a member of the community whose name has been chosen to be given to a new-born baby. Kwenzi-Mikala (1990: 114) comments as follows on this lexeme:

Un "homonyme" est une personne de la communauté dont on a choisi le nom pour l'attribuer au nouveau-né. Une fois le choix fait, il s'établit des liens spéciaux entre l'enfant et la personne qui a accepté de donner le nom. Cette espèce de parrainnage entraîne l'utilisation réciproque comme terme d'adresse du mot dînə qui signifie par ailleurs "nom". Le véritable but recherché à travers cette institution semble être de trouver un remplaçant à la personne sollicitée en assurant la perpétuation de son nom. Le choix peut porter aussi sur le nom d'un défunt, surtout si celui-ci n'a laissé aucun descendant. Il est encore plus clair, dans ce cas, qu'il s'agit d'honorer et d'immortaliser la mémoire du défunt.

Lexical items such as levée de terre, port de deuil, and levée or retrait de deuil are 
important funeral rites. After undergoing purificatory rites, members of the family usually wear mourning for the deceased (referred to as "port de deuil" in Gabonese French). The rising from the earth (referred to as "levée de terre" in Gabonese French) generally follows this ceremony. Finally, after a year, a celebration is officially held to end the mourning period ("retrait" or "levée de deuil" in Gabonese French) (cf. Mavoungou 2002). From these local forms of French, some seem to have been omitted. Readers will therefore miss items such as safou (the edible fruit produced by the safoutier), atanga (the edible fruit produced by the atangatier) as well as more recent lexical items such as fétichisme (fetishism), tresseuse (a female who plaits), marabout (a sangoma), maraboutisme (the craft of the sangoma), marabouter (to act as a sangoma), se saper (to dress elegantly), sapeur (an elegant person), absenter (to miss someone), grever (to be on strike), siester (to take a nap), régler (to have menstrual periods), tôler (to cover a house with corrugated iron), têter (to play a header with a soccer ball), tchatcher (to chat, to converse), tchatcheur (a good speaker), etc.

To summarise: Raponda-Walker's dictionary substantially adds to our knowledge of Gabon and the forms of French used in this country.

\subsection{Dictionaries and cultural activities}

As will be seen later in this article, any dictionary should reflect the lexicon of the language being treated. Because of traditional tasks or activities (fishing, hunting, agriculture, etc.), the vocabulary most commonly used in Gabonese speech communities encompasses names of plants, insects and animals as well as names of other natural phenomena (birth, death, traditional pharmacopoeia, traditional beliefs, etc.). In the majority of the dictionaries under discussion, an attempt has been made to include a reasonable number of words meeting these needs. In addition, where available, the scientific names of plants, insects and animals are supplied.

Gabon covers 267667 square kilometers, most of which is dense tropical forest, interspersed with savannah, and fed by a network of rivers of which the Ogooue is the most important. All seven lexicographic publications studied deal, in greater or lesser detail, with the names of the following fully protected animals of Gabon given in Table 1:

\begin{tabular}{|l|l|}
\hline \multicolumn{1}{|c|}{ Animal names } & \multicolumn{1}{c|}{ Scientific names } \\
\hline Aigle couronné & Stephanoaetus coronatus \\
\hline Aigle pêcheur & Haliaeetus vocifer \\
\hline Céphalophe à pattes blanches & Cephalophus ogilbyi crusalbaum \\
\hline Cercopithèque à queue de Soleil & Cercopithecus solatus \\
\hline Chimpanzé & Pan troglodytes \\
\hline Cobe des roseaux & Redunca arundinum \\
\hline Cobe onctueux & Kobus defassa \\
\hline Daman des arbres & Dendrohyrax arboreus \\
\hline Galago d'Allen & Galago alleni \\
\hline
\end{tabular}




\begin{tabular}{|l|l|}
\hline Galago de Demidoff & Galago demidovi \\
\hline Galago elegant & Galago elegantus \\
\hline Gorille $^{1}$ & Gorilla gorilla \\
\hline Hippopotame & Hippopotamus amphibious \\
\hline Lamantin & Trichechus senegalensis \\
\hline Lion & Panthera leo \\
\hline Oryctérope & Orycteropus afer \\
\hline Pangolin géant & Manis gigantean \\
\hline Panthère & Panthera pardus \\
\hline Pélican gris & Pelecanus rufescens \\
\hline Potto de Bosman & Perodicticus potto \\
\hline
\end{tabular}

Table 1: List of the fully protected animals of Gabon

Of all the dictionaries investigated, it is perhaps the Dictionnaire FrançaisMpongwé (1995) that best illustrates Gabon's wildlife as it exists today. If one looks at the macrostructural elements of this dictionary, it encompasses to a greater or lesser degree the names of the following partially protected animals of Gabon given in Table 2:

\begin{tabular}{|l|l|}
\hline \multicolumn{1}{|c|}{ Animal names } & \multicolumn{1}{c|}{ Scientific names } \\
\hline Bongo & Boocerus euryceros \\
\hline Buffle & Syncerus caffer nanus \\
\hline Céphalophe à dos jaune & Cephalophus silvicultor \\
\hline Chat doré & Felis aurata \\
\hline Crocodile du Nil & Crocodylus niloticus \\
\hline Crocodile nain & Osteolaemus tetraspis tetraspis \\
\hline Drill & Mandrillus (Papio) leucophaeus \\
\hline Éléphant & Loxodonta Africana \\
\hline Faux gavial & Crocodylus cataphractus \\
\hline Guib harnaché & Tragelaphus scriptus \\
\hline Hylochère & Hylochoerus meinertzhageni \\
\hline Ibis sacré & Threskiomis aethiopica \\
\hline Jaribu du Sénégal & Ephippiorhynchus senegalensis \\
\hline Mandrill & Mandrillus (Papio) sphinx \\
\hline Perroquet gris à queue rouge & Psittacus erithacus \\
\hline Potamochère & Potamochoerus porcus \\
\hline Python de Seba & Python sebae \\
\hline Serval & Felis serval \\
\hline Situtunga & Tragelaphus spekei gratus \\
\hline Spatule d'Afrique & Platalea alba \\
\hline Tantale ibis & Ibis ibis \\
\hline Tortue luth & Dermochelys coriacea \\
\hline Varan & Varanus niloticus \\
\hline Vautour palmiste & Cypohierax angolensis \\
\hline
\end{tabular}

Table 2: List of the partially protected animals of Gabon 
The dictionary also contains a fairly large percentage of the names of fish found in rivers and streams as well as the names of sea fish. Compare Table 3 and Table 4 in this regard.

\begin{tabular}{|l|l|}
\hline \multicolumn{1}{|c|}{ Fish names } & \multicolumn{1}{c|}{ Scientific names } \\
\hline Brochet & Hepsetus odoe \\
\hline Carpe de l'Ogooué & Oreochromis schwebischi \\
\hline mâchoiron & Chrysichthys nigrodigitatus \\
\hline Mormyre & Brienomyrus longicandatus \\
\hline ngotu & Heterobranchus longifilis \\
\hline oyara & Schilbe grenfelli \\
\hline Petite anguille épineuse & Aethiomastacembelus marchei \\
\hline Poisson à tête de serpent & Parachanna obscura \\
\hline Protoptère & Protopterus dolloi \\
\hline Sardines des lacs & Pellonula vorax \\
\hline Silure & Clarias gariepinus \\
\hline Synodontis & Synodontis batesii \\
\hline Tetra africain & Brycinus macrolepidotus \\
\hline Tilapia & Tilapia cabrae \\
\hline
\end{tabular}

Table 3: List of the names of fish found in rivers and streams of Gabon

\begin{tabular}{|l|l|}
\hline \multicolumn{1}{|c|}{ Fish names } & \multicolumn{1}{c|}{ Scientific names } \\
\hline Bar & Pseudotolithus typus \\
\hline Bécune & Sphyraena afra \\
\hline Bossu & Pseudotolithus elongatus \\
\hline Carangue & Caranx hippos \\
\hline Dorade grise & Pomodasys peroteti \\
\hline Engil & Lutjanus dentatus \\
\hline Espadon voilier & Istiophorus albicans \\
\hline Grand capitaine & Polydactylus quadrifilis \\
\hline Mâchoiron de mer & Arius latiscutatus \\
\hline Mérou noir & Epinepphelus marginatus \\
\hline Mullet & Mugil cephalus \\
\hline Plexiglass & Galeoides decadactylus \\
\hline Raie Pastenague & Dasyatis ukpam \\
\hline Requin bouledogue & Carcharhinus leucas \\
\hline Sardine des estuaires & Ethmalosa fimbriata \\
\hline Tarpon & Tarpon atlanticus \\
\hline
\end{tabular}

Table 4: List of the names of sea fish of Gabon.

In spite of this, there are some shortcomings. Although dialectal differences have been clearly established, many dictionaries of Gabonese languages are biased toward one dialect. This is detrimental to users of the speech community. When macrostructural elements in a particular dictionary are from one 
dialect, users of the other dialects too often do not recognize themselves in the dictionary. In existing dictionaries compiled with Fang-Atsi as a treated language, the lexical stock mainly comprises fishing terms (e.g. several kinds of fish), because Fang-Atsi people are predominantly fishermen. As a result, these dictionaries do not have many terms relative to hunting, harvesting and agricultural activities common to other Fang communities. The point in question is illustrated in the treatment of the following lemmata: aba, abò and poisson.

(5) Dictionary excerpt from Martrou 1924: 21 and 23.

Aba Petit poisson de ruisseau.

Abò Variété de grenouille brune et tâchetée.

- Espèce de crabe. Abo-kara.

— evus, araignée crabe dont la piqûre est venimeuse.

(6) Dictionary excerpt from Galley 1964: 520-521.

Poisson $k o(\mathrm{~m})$, kos $(\mathrm{m})$. Noms de poissons (environ septante): abem (b) petit poisson; adua (bm), famille des ntetom (b), akom (h), famille des ñgol (b), syn.: mvè (h); akweghe (h), petit poisson: alap ékôni (bh); grosse carpe, syn.: ñkãn ékôni (hh); amokh (h), petit poisson noir à écaille, syn. ñgoméésa $(\mathrm{mb})$; andôndôe $(\mathrm{m})$, petit poisson; anduma $(\mathrm{h})$, grand poisson; anyia (b), poisson (b) poisson torpille ou silure électrique, voir ala anyia $(\mathrm{mb})$, añgeñgeme $(\mathrm{h})$, petit poisson; añgwañ (b), petit poisson; añgwekh ékôni (hh), carpe encore petite; aveña (bm), hénioque, poisson plat en forme de cercle, surtout dans l'eau de mer, syn.: évulababa $(\mathrm{bm})$; ayaol $(\mathrm{h})$, poisson sole qui ressemble à une limace (ayol); bè (h), petit poisson de la famille mvagha (b);

... ñgoña (h) ou moôkh (h), petit poisson, variété de keme (h), ñken (h), petit poisson qui se cache dans le sable sous l'eau, la tête seule se voit; ñkôghli (b), poisson raie, voir ce mot; ôbar (b), poisson qui nage sur le dos, famille ntetom (b).

The same situation is true of the vocabulary denoting spiritual activities (traditional initiation rites). Dictionaries of Fang-Atsi or Fang-Mekè, for instance, give more data regarding the Bieri (worshipping of a person's ancestral skull) which forms part of their culture, than about the Melane (a masculine initiation and secret society) that speakers of these two dialects do not practice.

\subsection{Dictionaries and cultural ethics}

Dubois and Dubois (1971) hold that terms do not only refer to the words of a language, they are not only objects of the metalanguage of linguistics, but they also refer to cultural statements, a worldview. In an article dealing with cultural practices of English-speaking North Americans, French Canadians and the French as they are conveyed through advertising, Quillard (1999: 46) points out: "La nudité ou semi nudité ne choque pas les Français. Considérée comme 
naturelle, elle n'a pas lieu de d'être cachée ou censurée" (Nudity or semi-nudity do not shock the French. Regarded as natural, it does not have to be hidden or censured.) This is not the case in Gabon. Under normal circumstances, Gabonese are extremely decorous. The private parts of the body are taboo and are spoken of only in metaphors, euphemisms and other rhetorical expressions.

It is a well-attested fact that any dictionary should reflect the lexicon of the language being treated. The lexicon in question must encompass all its aspects, including taboos. In the existing dictionaries of the Gabonese languages, various terms referring to some cultural taboos (particularly about sex and some parts of the body) are found. Compare the following articles as examples:

(7) Dictionary excerpt from Largeau 1901: 388.

INCESTE. N'sem nden (grand péché). Celui qui le commet. Môr a bo' nsem ndem. Encyclopédie: L'inceste, chez les pahouins, est limité à ces définitions: 1 Rapports sexuels entre un homme, sa mère, sa sœur ou sa fille; 2 Mêmes rapports entre une femme mariée et les fils des autres femmes de son mari ...

(8) Dictionary excerpt from Martrou 1924: 27.

Akan Aine, hanche, cuisse.

(9) Dictionary excerpt from Galley 1964: 423.

Avorter (femme), kwé abmum (hb). Celui qui fait avorter une femme, ñkwé abmum (hb).

(10) Dictionary excerpt from Raponda-Walker 1995: 17.

anus N. esulu, orolo.

(11) Dictionary excerpt from CMA 1966: 44.

fesse - dirangi

In (10) and (11), it is rather inconceivable to supply a direct translation equivalent for the lemmata anus and fesse, since in Gabonese cultures, reference to these parts of the body require euphemisms.

It is part of the responsibility of the lexicographer to identify taboo terms and to warn the user against their indecorous nature. In this regard, J. Dubois (1970: 43) mentions that the lexicographic speech is not only a pedagogical statement about the language; it is also a cultural training whose propositions must be culturally accepted. As pedagogical aids dictionaries have to make users culturally aware of the underlying worldview of the language or languages being described. That is why dictionaries also aim to constitute themselves as an explicit cultural norm for the linguistic community. The compilation of dictionaries is useless if the target group they are compiled for, rejects them. 
In (8), (10) and (11), objections should not be made with regard to the inclusion of akan, anus and fesse as macrostructural elements but rather with regard to the absence of contextual data addressed to the lemmas, given their taboo nature. Compared to the above-mentioned articles, the treatment of the article of the lemma inceste is quite satisfactory. In fact, as long as the explanation of meaning ( $n^{\prime}$ sem nden = grand péché) continues, the user is warned against the unmentionable nature of the lemma.

The aim of dictionaries to constitute themselves as an explicit cultural norm for the speech community goes a bit further in the article on the lemma conseil which implicitly contains the following theme: respect for traditional authority and elders. The encyclopedic section of this article in both source language and target language is worth quoting in extenso:

(12) Dictionary excerpt from Largeau 1901: 190-191.

CONSEIL $1^{\circ}$ avis sur la manière d'agir, de se conduire, Alôa, Pl. me lôa (b); Alôgha, Pl. me logha ... - Encyclopédie. Les Pahouins ont leur Code de morale qu'ils transmettent religieusement à leurs enfants. Nous croyons devoir donner ciaprès, avec le texte original tel qu'il nous a été dicté, un exemple des conseils donnés par les vieillards aux jeunes gens après la cérémonie de la circoncision. La traduction en est aussi littérale que possible.

$$
\text { ME LÔA }
$$

Mi yôm mia zô bonghe na: ngue wa yi tabe ne ntä̈ wouïa, mvoghi; o dighe $\overline{z u}$ éba bon̈ga, wona kagha $\bar{z} u$ éba bon̈ga, wona o wôghā ndzough, o oboā okôkôr. O kagha bo' ke wôghe azô me zô we di, wona wémieñ o yènā dô. E ma zô we va, ke tabe ési; kan' ghi wa dighi bon̈ga e mi lam; o lough. O kagha ke wa dighi bon̈ga, o bômi, o soli ne ñe, be mani vegh. Wona, wa tabe ési, o bôme ne é mon̈ga wouïa; a non' ghi abem; a biê mon̈-a-fam̈, o yô we éso; wona o tab' ési nôm-o-môr. O kagha yèn̈, o boā ne nló mvê; wona o ñegheïa. Nina: me zô me nôm me nga' zô we, o wôghā mô? - Ana o bo' ke mô wôghā, ve wa bo' okôkôr.

$$
\text { LES CONSEILS }
$$

Les vieillards disent aux jeunes gens que: si tu veux rester avec ton bien, sois sage; ne débauche pas les femmes des autres. Si tu débauche les femmes des autres, alors tu auras des désagréments, tu seras malheureux. Si tu n'écoutes pas ce que je te dis, alors toi-même verras cela: Quand je te parle ici, ne reste pas inactif; va voir les femmes dans les villages; tu (en) épouse (une); si tu vas voir les femmes, tu (en) amènes (une), on la paie. Alors tu te fixes, tu couche avec ta femme; elle devient enceinte, elle accouche d'un garçon auquel tu donnes le nom de ton père; puis tu restes vieillard. Si tu vois (cela), tu as été un homme sensé; alors tu es aimé. Il dit: les sages paroles que je t'ai adressées, les as-tu comprises? - Si tu ne les a pas comprises, tu seras malheureux.

With regard to the Encyclopédie pahouine, Mavoungou (2001: 125) has mentioned the existence of special articles focusing on cultural data presented in both source language (to the left) and target language (to the right) in two columns set apart typographically, and therefore clearly perceived by the user. In 
the encyclopedic section of the above article, introduced by the structural marker Encyclopédie, Largeau states that the Fang take great pride in their morality, and the youth are instructed from early childhood to develop a sense of uprightness in all their undertakings. He also mentions that he thought that more data regarding the moral codicil in the Fang community was necessary for a better understanding of the treated lexical item. To fulfil these anticipated expectations on the side of the users, Largeau proposes a text containing some advice given by elderly people to young people undergoing circumcision rites. The French version of the text gives a word-for-word translation of the Fang text. The main purpose here is to describe the value system, which is reflected in the use of the source language. The text riddle instructs young people not to sleep around with married women, but to assume adult duties and responsibilities as early as possible.

\subsection{Dictionaries and language registers}

According to Dubois and Dubois (1971), language registers are indications that define the attitude of the community regarding verbal behaviour and the way oral and written speech are considered. Terms and expressions become indices and social symptoms: they show that the speech which contains them, belongs to a specific social group. They add that the dictionary informs about different language levels and shows how to ascertain these levels, to delineate them and culturally to censor them: one who uses popular or familiar words or expressions does not belong to the so-called "good society". The word is a mark of recognition. In French society for instance, the way people speak (the language level or register they use) can indicate to which social milieu they belong or what their educational background is. It is a commonly used practice in dictionaries to mark, e.g. familiar, popular and slangy words and expressions. This is done to show that these words and expressions are not part of the standard language. Dictionaries of Gabonese languages hardly contain markings signalling language levels. There are two explanations for this lack of level markings:

- The first explanation is the fact that Gabonese languages are not standardized yet. In this context, it could be difficult to distinguish the standard level from the others (popular, familiar or slangy).

- The second explanation is related to the first one. There is hardly ever a relation between someone's linguistic proficiency and his/her social status. A person from a very modest background could have a high proficiency in the use of his/her mother tongue and vice versa.

\subsection{Dictionaries and culture maintenance}

Dictionaries try to satisfy the curiosity of the community. The community 
wants to know more about its past. By including cultural customs (even those which are no longer utilized or practiced) in dictionaries, lexicographers can help the society to know about the past and to keep it alive for future generations. In many dictionaries of Gabonese languages, terms referring to old customs and activities are included. The Encyclopédie Pahouine by Largeau, is a good example in this regard. An important introductory part, presenting several Fang traditions, is included in this book. Aspects related to marriage, hunting, fishing, agriculture, resolution of problems, accommodation, social status, initiation rites, etc. in Fang society are broadly presented. Even if some of the described customs are obsolete nowadays, their existence in dictionaries give younger generations the opportunity to learn more about their culture. The dowry, for instance, was not practiced in the same way in the past as it is today. Dictionaries can teach their users about the real meaning of the dowry in traditional Fang society as illustrated in the following article from Galley's Dictionnaire fang-français et français-fang:

(13) Dictionary excerpt from Galley 1964: 445.

DOT de mariage qui se payait autrefois avec de la monnaie de fer, nsua bikî (bmb), bikî (b), évegha (b), alo kama (hh), bilî bi kama (bh), mevekh (b). Actuellement on paie en marchandise et en argent. Compte des choses données en dot d'une part et en cadeaux (ñgañ) d'autre part, $f a$ (h). On fait le compte, $b a$ zia fa (hh). Paiement de la dot (la plus grosse part), mbîkine (h), mbukîne (h). Premier versement de la dot, petit versement de début, ôlum (h), bem ôlum (bh). Choses que le beau-père donne à son gendre, mevale (h), ñgañ (m). Tout ce qu'on ajoute à la dot en plus des vieux fusils (couteaux, cuillères, chat, boubou), ntsim (b).

Although this dictionary article provides the user with a good deal of information about the bride price in Fang culture, reservations can be made with regard to the absence of contextual entries addressed at the lemma sign dot (dowry). Concerning this point, Busane (1990: 33-34) has pointed out that the word for the English bride price has been treated unsatisfactorily in several bilingual dictionaries of African languages - unsatisfactorily because the word in African languages meaning bride price is usually associated with the English dowry on the one hand and with the French dot on the other. However, dowry and dot in the English and French traditions convey the following meaning: Possessions that a woman brings to her husband under a marriage contract (Les biens qu'une femme apporte à son mari lorsqu'elle rentre dans un contrat de mariage). This meaning is different from that which the term bride price conveys. In an attempt to co-ordinate source and target language forms, lexicographers in the English-speaking world compiling dictionaries of African languages generally use the lexeme bride price as a translation equivalent for the word meaning "a payment of money or cattle made to the family of a woman when she is married".

In the French-speaking world, apart for "dot", there is no suitable transla- 
tion equivalent for the word meaning "bride price" in the African languages. In keeping with the user-perspective and given the fact that dot does not capture the dominant meaning of the Fang word nswá (bride price), the lemma sign dot as given in (13) should be accompanied by contextual entries as it occurs in (14). In spite of all these shortcomings, the treatment of the article dot given in (13) does not only explain how the bride price was paid but it also accounts for the different forms of payment. The payment was usually made in metallic bars (the traditional currency before the arrival of the metrical colonial currency of Franc CFA, Central African Francs) together with various goods and gifts. In addition, paying of the bride price was hardly ever a single, once only transaction. It was not about buying a wife as goods are purchased. Marriage was not the union between two individuals but a contract between different families. This union was performed by a kinship that could not be dissolved by the divorce of the married couple.

(14) DOT (au sens que ce mot a dans les langues gabonaises) de mariage qui se payait autrefois avec de la monnaie de fer, ...

In Les plantes utiles du Gabon, the lexicographic treatment offered for plant names makes provision for the inclusion of a significant amount of cultural data regarding, e.g. traditional pharmacopoeia together with dietary practices and traditional beliefs. Cultural information on traditional pharmacopoeia, for example, can be retrieved by users at Irvingia gabonensis:

(15) Dictionary excerpt from Raponda-Walker and Sillans 1961: 207-208.

3. IRVINGIA GABONENSIS Baill. - Manguier sauvage (colons); Oba. Arbre de grande taille, muni de forts accotements aliformes à la base. Ecorce cendrée roussâtre. Feuillage très dense. Feuilles alternes, simples et entières, luisantes à face inférieure. Stipules courtes, promptement caduques. Fruit drupiforme, à pulpe charnue, plus ou moins amère et très fibreuse. Noyau dur renfermant une graine unique, aplatie, très oléagineuse. Bois très dur, d'un blanc-rosé, lavé de jaune clair, putrescible dès qu'il est exposé à la pluie. Très répandu dans tout le Gabon. Cf. PL. XXI.

Us. - Le bois, difficile à travailler, mais très résistant, est utilisable pour la grosse charpente, à l'abri de la pluie. Les indigènes l'emploient pour la confection des pilons à mortiers ou auges. Les ménagères recueillent les amandes des fruits pour préparer le pain d'odika (mpongwè, galoa, nkomi, orungu), ndòc (fang), mudika (éshira, bavili, bapunu, masango, banzabi), d'un usage courant dans la cuisine gabonaise. La pulpe amère se mange aussi. Le chocolat indigène, réduit en poudre, peut s'appliquer sur les brûlures. Il intervient encore dans la composition de certains remèdes astringents. En outre, on consomme les râpures de l'écorce dans une grosse banane verte cuite sous la braise, pour enrayer la diarrhée ou la dysenterie; ou bien on la fait macérer pour s'en servir en lavement. À cause de sa fécondité, cette essence est considérée comme un porte-bonheur pour les plantations vivrières. Avec son écorce on fait des talismans pour donner ou rendre la fertilité au sol. 
Noms vernac.: Oba (mpongwè, galoa, ikomi, orungu); uba (mitsogo, bavové); wéba (apindji); wiba (ivéa); bwibè (benga); mubè (bakota); mwiba (éshira, bavarama, bavungu, bapunu, balumbu, loango, masangu, ngowé); andòc (fang); vidòkò (béséki); béképé (bakèlè); ondimba (mindumu); mundjiku (bavili); mundjiku (baduma); mundjika (banzabi).

This dictionary article is divided into three sections distinguished typographically and therefore clearly perceived by the user. The first section deals with the description of the plant listed. The second section introduced by an italicised structural indicator (Us. = Uses), deals with uses. In the third section, the user is provided with a list of indigenous names in some 21 Gabonese languages. An italicised structural marker (Noms vernac. = Vernacular names) also introduces this last section of the article. Section 2 of the text can be translated as follows:

The wood, difficult to carve but very resistant, is used to make frames for huts. The indigenous population uses it to make pestles and mortars. Housewives collect seeds of the fruits in order to prepare the dika bread (mpongwè, galoa, nkomi, orungu), ndòc (fang), mudika (éshira, bavili, bapunu, masango, banzabi), widely used in Gabonese cuisine. The bitter pulp (of the fruit) is also edible. The powder obtained from the seeds can be applied to burns. It is also used in the preparation of some astringent medicines. Moreover, raspings of the bark together with a big banana (plantain) that is cooked under hot ashes are used as a remedy for diarrhoea or dysentery. However, a decoction of the bark can also be used for enemas. Because of its fecundity, this tree is believed to bring luck to farms (alimentary plantations). Talismans that give or restore the fertility of the soil are made from its bark.

With regard to the second topic (traditional beliefs), the treatment of the article of the lemma Strychnos icaja, for example, offers the user a great deal of cultural information as can be seen in (16):

(16) Dictionary excerpt from Raponda-Walker and Sillans 1961: 269-270.

7. strychnos icaja L. - Poison d'épreuve. Arbuste sarmenteux de la forêt dont toutes les parties sont amères. Feuilles opposées, d'un vert terne, coriaces et parcheminées, avec de grandes nervures en demi-cercle. Fleurs en cymes axillaires. Fruits de la grosseur du pouce, rouge à maturité. Racines à écorces rouge vif.

Us. - L'écorce de la racine est fréquemment employée comme poison d'épreuve, dans les ordalies, pour prouver l'innocence ou la culpabilité des accusés. On fait macérer des râpures de la racine dans une grande tasse ou une calebasse. La fermentation a lieu aussitôt et l'eau prend bientôt une teinte rougeâtre. Une fois l'effervescence apaisée, l'accusé saisit la tasse ou la calebasse et en avale le contenu. Il faut noter qu'à faible dose, cette drogue ne détermine pas la mort; elle est simplement enivrante et diurétique. Comme contre-poison, on préconise les excréments humains avec des oeufs de poule et du jus de canne à sucre. 
Noms vernac.: Ikaza (mpongwè); ikadja, kwa (benga); kasè (bakèlè, béséki); mbundu (galoa, nkomi, orungu, ngowé, éshira, bavarama, bavungu, bapunu, balumbu, bavili, baduma, banzabi, loango, masangu, mindumu); mbondo (ivéa, bavové, bakota); moléla (apindji); mwéya (mitsogo); bilon (fang).

Section 2 of the article dealing with uses of the plant can be translated as follows:

The bark of the root is commonly used in trials by ordeal in order to prove the innocence or the culpability of the accused. Bark from the root has to be macerated in a large bowl or in a calabash. The fermentation takes place immediately and the water soon turns into a reddish colour. After the effervescence, the accused takes the bowl or the calabash and drinks from it. It should be noted that a small dosage of this drug does not kill; it is simply intoxicating and diuretic. As an antidote, human faeces together with chicken eggs and sugar cane juice are recommended.

\subsection{Dictionaries and the standardization of culture}

For a language with several dialects, dictionaries are usually compiled in one dialect. The gaps between dialects from the same language are not only about linguistic forms, but also about culture, activities and habits. The compilation of a dictionary in a certain dialect means that the lifestyle of the speakers of that dialect will also be presented. Unconsciously, dictionary users will be influenced by that dialect. In other words, they will tend to use the underlying customs of the dialect that is described in the dictionary instead of following their own way of life conveyed by their own dialects. Therefore dictionaries somehow impose the use of the included dialect and favour its customs as the standard ones. By standardizing the language, dictionaries also standardize the culture. In the Gabonese context, this situation has not applied yet, either because, in many Gabonese languages, dictionaries do not have a long existence, or because the existing dictionaries are not available to the public at large. As a result, they cannot really influence the use of these languages.

\section{Conclusion}

In this article dealing with the reproduction of Gabonese cultural aspects in existing dictionaries of Gabonese languages, the primary focus has been on the rendering of words of a traditional nature, e.g. the names of plants, insects and animals, as well as the names of other natural phenomena. If the articles are looked at along encyclopedic lines, then all the dictionaries under discussion give a wealth of information about Gabon: its place-names, flora and fauna. Moreover, most of these dictionaries contain introductions encompassing a description of a wide variety of customs and traditions typical of Gabonese cul- 
tures. To a larger or lesser degree, all these dictionaries encompass essential Gabonese cultural aspects such as dietary practices, sexuality, mythology, traditional pharmacopoeia, the kinship system, hospitality, and respect for traditional authority and elders.

Urbanisation, the destruction of the environment, the westernisation of communities and the change in life-style have already been responsible for a serious decrease in the proficiency of mother-tongue speakers of Gabonese languages. This is why the cultural dimension is becoming one of the central factors in Gabonese lexicography. Because of the widely recognized importance of the user in dictionary making, modern-day lexicographers are striving to put user-friendly products on the market. These products also encompass the cultural dimension.

\section{Endnote}

1. Lexical items in this table are differentiated by topographic means. Items in bold type refer to lemmata as they appear in the dictionaries consulted, whereas words in roman characters either occur as microstructural elements or are insertions by the authors.

\section{References}

\section{Dictionaries and encyclopaedias}

Église Évangelique du Sud-Gabon. 1966. Dictionnaire français-yipounou / yipounou-français. Mouila. Galley, S. 1964. Dictionnaire fang-français et français-fang, suivi d'une grammaire fang. Neuchâtel: Henri Messeiller.

Largeau, V. 1901. Encyclopédie Pahouine. Éléments de grammaire et dictionnaire français-pahouin. Paris: E. Leroux.

Martrou, L. 1924. Lexique FÃN-FRANÇAIS. Paris: Procure Générale (des Pères du St Esprit)/Abbeville: Imp. Paillard.

Raponda-Walker, A. and R. Sillans. 1961. Les plantes utiles du Gabon: essai d'inventaire et de concordance des noms vernaculaires et scientifiques des plantes spontanées et introduites du Gabon. Paris: Lechevalier.

Raponda-Walker, A. 1995². Dictionnaire Français-Mpongwé. Éditions Raponda-Walker. Classiques Africains. Libreville: Imprimerie St Paul.

\section{Other}

Busane, M. 1990. Lexicography in Central Africa: the User Perspective, with Special Reference to Zaïre. Hartmann, R.R.K. (Ed.). 1990. Lexicography in Africa: 19-35. Exeter: University of Exeter Press.

Dubois, J. 1970. Dictionnaire et dicours didactique. Rey-Debove, J. (Ed.). 1970: 34-47.

Dubois, J. and C. Dubois. 1971. Introduction à la Lexicographie: "Le Dictionnaire". Paris: Larousse. 
Kwenzi-Mikala, J.T. 1990. L'anthroponymie chez les Bapunu du Sud-Gabon. Pholia. Revue du Laboratoire de Phonétique et Linguistique Africaine 5: 113-120.

Mavoungou, P.A. 2001. Macro- and Microstructural Issues in Mazuna Lexicography. Lexikos 11: 122-138.

Mavoungou, P.A. 2001a. La mondialisation et la lexicographie trilingue ou plurilingue au Gabon. Emejulu J.D. (Ed.). 2001: Éléments de lexicographie gabonaise Tome I: 160-183. New York: JimacsHillman.

Mavoungou, P.A. 2002. Synopsis Articles in the Planning of a Trilingual Dictionary: YilumbuFrench-English. Lexikos 12: 181-200.

Mihindou, G-R. 2001. Apports des missionnaires à la lexicographie gabonaise: dictionnaires bilingues Fang-Français/Français-Fang; Français-Yipounou/Yipounou-Français; Français/ Mpongwé. Emejulu J.D. (Ed.). 2001. Éléments de lexicographie gabonaise Tome I: 7-37. New York: Jimacs-Hillman.

Nyangone Assam, B. and P.A. Mavoungou. 2000. Lexicography in Gabon: A Survey. Lexikos 10: 252-274.

Quillard, G. 1999. Publicité, traduction et reproduction de la culture. Babel 45 (1): 39-52.

Rey-Debove, J. (Ed.). 1970. La lexicographie. Langages 19.

Rittaud-Hutinet, C. 1980. Lexique. Nsuka-Nkutsi, F. (Ed.). 1980. Éléments de description du Punu: 193-245. Lyons: Presses Universitaires de Lyon. 